\title{
Modern Technology and Human Extinction
}

\author{
Robert A. Schultz \\ Woodbury University, Burbank, CA, USA
}

bobschultz10635@gmail.com

\begin{abstract}
[Note: Portions of this paper were previously published in Schultz, 2014.]

The purpose of this paper is to describe and explain a central property of modern technology that makes it an important potential contributor to human extinction. This view may seem strange to those who regard technology as an instrument of human growth. After discussing modern technology and two important candidates for extinction, other technological candidates for serious contribution to human extinction will be examined. The saving contribution of information technology is also discussed.
\end{abstract}

Keywords: technology, classical technology, modern technology, information technology, gradual extinction, sudden extinction.

\section{Introduction}

Helping to further human extinction is not a feature of all technology, but rather of technology we can call modern. In this paper, modern technology is considered to be technology since the industrial revolution. Its distinctive feature is that it regards everything as resources for its own processes. Serious conflicts with the ecosystems that support all life are inevitable and not easily preventable.

\section{A Very Brief History of Technology}

Technology can be thought of as having four stages:

>> Proto-technology, early tool development before civilization, one million, possibly 2 million years old.

>> The classical technology of agriculture and cities that enabled the rise of civilization, roughly 10,000 years old.

>> Modern technology enabled by science, about 500 years old. (Heidegger 1955)

>> Postmodern technology, replacements for naturally occurring products, about 100 years old.

Material published as part of this publication, either on-line or in print, is copyrighted by the Informing Science Institute. Permission to make digital or paper copy of part or all of these works for personal or classroom use is granted without fee provided that the copies are not made or distributed for profit or commercial advantage AND that copies 1) bear this notice in full and 2) give the full citation on the first page. It is permissible to abstract these works so long as credit is given. To copy in all other cases or to republish or to post on a server or to redistribute to lists requires specific permission and payment of a fee. Contact Publisher@InformingScience.org to request redistribution permission.
The use of any technology other than the proto-technology of hunter-gatherer societies takes up a remarkably short portion of human existence on the planet. Current estimates of the presence of the species Homo sapiens are about 200,000 years. Classical technology has been a possible human mode of existence for 10,000 years, no more than $5 \%$ of hu- 
manity's time on earth. Modern technology's 500 years represents much less than $1 \%$ of humanity's time on earth and postmodern technology's 100 years even less.

In a preliminary way, we can distinguish between classical and modern technology, on the one hand, and between modern and postmodern technology as follows:

Classical technology can always be thought of as supplying means for some pre-existent ends. It enhances the development of the social and economic forms of agriculture and civilization. Although civilization is not possible without agriculture, agriculture is possible without developed classical technology. Modern technology differs in having its own distinctive ends and point of view.

Postmodern technology results from replacing natural products with entirely technologically-produced ones. Products developed in the 20th century are often of this kind. They typically have much greater negative effects on the environment, very often because they are primarily produced from petroleum, which is highly toxic. Petroleum derivatives are also highly toxic.

Here is a timeline of some of the major postmodern technologies:

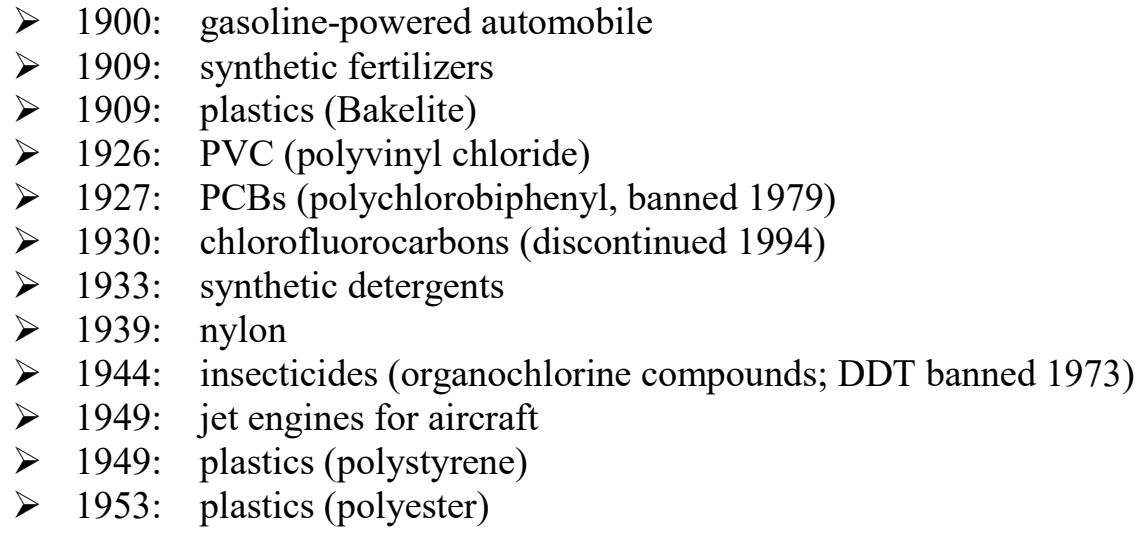

The dramatically more environmentally destructive products of postmodern technology and techniques arose in the 20th century. This does not mean modern technology was not destructive. Although there are some conflicts between classical technology and the environment, modern technology makes things worse. Two recent examples are global in their extent: Chlorofluorocarbons and climate change.

The philosopher Martin Heidegger saw most clearly that modern technology has its own point of view which is completely separate from any other structure of human aims and purposes. The critical feature of modern technology is its willingness to treat anything as a resource to be reordered in the furtherance of other aims, usually its own. Heidegger, in his essay "The Question Concerning Technology," concludes that modern technology is an independent force in human existence. It builds a new and incompatible order on top of what was there, primarily in order to extract and store energy for later uses (Heidegger, 1955, pp. 14-17).

The point of view of modern technology regards everything as a potential resource, as "standing reserve" to be used or reused later in other related processes. A forest has status only as a timber resource. Land itself is only a resource for the building industry. Even human beings themselves become "human resources" from this point of view. Or they become "consumers." Or ill people become a "supply of patients for a clinic". Many distinctive modern technologies embody this notion of "standing reserve" in their very conception. Thus, electric power, whether in the form of available current or batteries, is always entirely standing reserve, on hand for potential use. This way of looking at things, insofar as it ignores the previous pattern of processes, uses, and 
ends, is inherently "violent" in its effects on those processes, especially concerning the environment.

Once modern technology is properly conceptualized, examples abound all around us to confirm its status as an independent incompatible force for the rest of the environment. Extractive industries tend to be extremely destructive to the rest of the environment. It is almost a daily occurrence to read of the latest oil spill and its destructive consequences. Coal mining uses a technique called mountaintop removal. The result is a devastated, unusable landscape. Chemical petroleum-based pesticides threaten the extinction of species like the Monarch butterfly and as a side effect cause an increase in cancer in human beings. These extractive industries are typically producing the materials to be used in the processes of modern technology. Somewhat more indirect examples such as deforestation and genetic engineering will be discussed in a later section.

Technologists very often view technology as a neutral means. An anonymous reviewer of one of my writings put it thus: "What counts is how technology is being applied, and for which purposes." This statement has some merit for classical technology but has no merit for modern technology. One consequence of the statement is that technology itself can't be assessed. One way to see the disastrous consequences of this view is to apply it to an ecosystem-threatening application of technology. Chlorofluorocarbons were carefully tested before being released into the environment. It was an unintended and unforeseeable side effect of the application that produced the ecosystem-threatening thinning of the ozone layer. There was nothing wrong with the application. So if applications are all that needs to be considered, there is nothing further to be considered and we must let the ozone layer be destroyed.

Chlorofluorocarbons and their effect on the ozone layer ought to be more than sufficient to put us on notice that with the best of intentions developers of new technology can find themselves with world-destroying consequences. A "safe" synthetic compound, chlorofluorocarbon (CFC), developed in the 1940s for use in air conditioners and aerosol cans turned out to be inert except in the upper atmosphere, where it destroys the ozone layer which protects us from ultraviolet radiation. The ozone layer protects all life against excessive ultraviolet radiation, and when it is damaged or destroyed the surface of the planet on which we and all animals and plants live is subjected to dangerous levels of ultraviolet. There are two disturbing implications: (1) There does not seem to be any way that this result of normal chemical engineering could have been predicted; (2) All life has evolved under the protection of the ozone layer; this sudden a change has unpredictable consequences for all life forms in the ecosystem (Asimov \& Pohl, 1991, pp. 91-110).

Global warming and climate change are another global conflict between modern technology and the environment. Global warming is an overall effect caused by the increase of levels of socalled "greenhouse gases," of which carbon dioxide is the most prevalent. They are called "greenhouse" gases because they increase the ability of the earth's atmosphere to retain heat, just like the panes of glass in a greenhouse. Yet carbon dioxide at the local level is nontoxic and the levels which produce global warming have no impact on any kind of life. ${ }^{1}$ The increased levels of greenhouse gases are the by-product of modern technology. Carbon dioxide is the most prevalent gas, with much of it coming from the burning of fossil fuels in the internal combustion engines of cars, buses and trucks. The size of temperature increase produced by the increased carbon dioxide is difficult to predict, but the size of the increase would normally happen over tens of thousands of years. As of 2014, the average air temperature has increased 3 degrees Fahrenheit since 1970. One current consequence is storms of increasing severity. Warmer atmosphere holds

\footnotetext{
${ }^{1}$ U.S. Representative Michelle Bachman made in 2011 public statements indicating she does not grasp this point. A sizeable number of U.S. citizens and politicians are hostile to the idea of global warming. In this the U.S. is pretty much alone amongst developed nations and even developing nations such as China.
} 
more water vapor, which supplies more energy for storms and rainfall. Hundred-year storms and floods have become common (Hansen, 2009, p. 253).

Severe strains on plants and animals are also happening. Polar bears are famously losing essential parts of their environment, that is, frozen ocean. Some animals can move to more congenial colder places when the atmosphere warms, but trees cannot move with anywhere near the speed necessary to cope with global warming. And some animals and plants on mountains run out of space--they are at the top of the mountain with no further higher cooler places to move to (Wilson, 2002, p. 69).

Human-caused global warming, because it directly affects human economics, has aroused contrary argumentation based on the premise that human economic activity cannot possibly affect the entire environment. This is probably wishful thinking. Our atmosphere's composition is not a given; the amount of carbon actually in the atmosphere is about the same as that present in the totality of living beings (the "biomass"). Consequently, adding the carbon locked up in fossils in large quantities is likely to have an impact. In Figure 1, the black arrows indicate carbon exchanges exclusive of human beings. The red arrows are carbon added by human activity. As you will notice in Figure 1, the amount of carbon dioxide in the atmosphere (597 billion tons) is one quarter of the amount contained in soil and vegetation (2300 billion tons). But soil contains about 1600 billion tons, leaving 610 billion tons contained in vegetation, about the same as that in the atmosphere. Consequently, human activity adding 6.4 billion tons per year will make an impact. In 20 years, that would be an extra 128 billion tons of carbon dioxide.

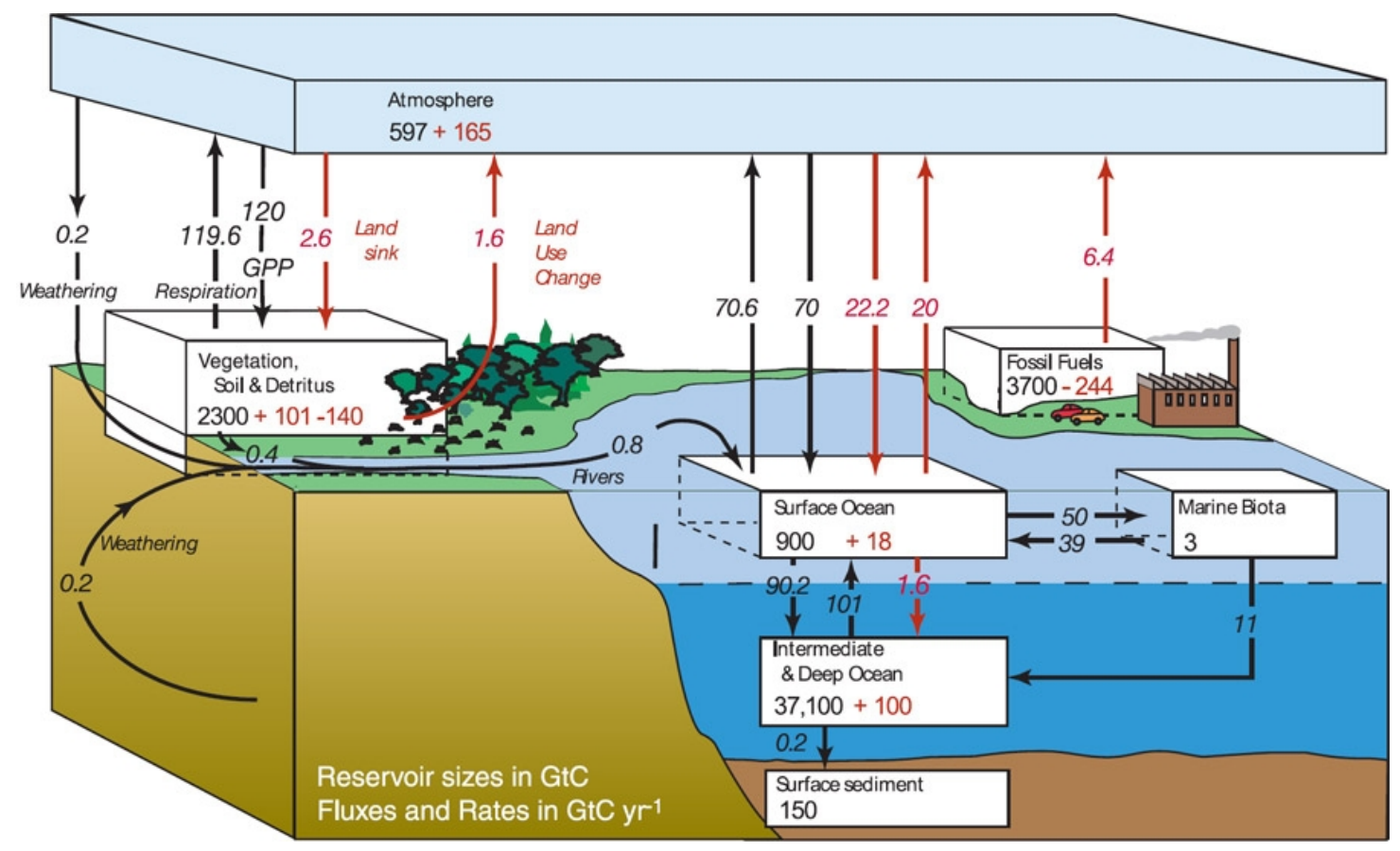

Figure 1 Carbon Cycle

(from IPCC AR4 WG1 by permission of International Panel on Climate Change)

These two examples should make it clear that even if we can resolve global problems like these (likely with the aid of technology) there is no reason to believe that other equally difficult problems will not arise concerning our ecological support system. This is the reason why a correct diagnosis of the nature of modern technology and its place in human activity are essential. The critical point is that the world-destroying consequences of technology cannot be limited to the two we have experienced so far. 
The issue of human-caused climate change has caused corporations whose (short-term) interests are affected to distribute not only false information about a lack of scientific consensus but also false scientific information ${ }^{2}$, rejected by $95 \%$ of climate scientists (Doran \& Zimmerman, 2009) A recent discovery is that the large fossil fuel corporation Exxon-Mobil has actually believed that human-caused climate is occurring and still spent tens of millions disseminating information skeptical about climate change.(McKibben, 2015) Time reporter Bryan Walsh found a concerted effort by large conservative corporations and other organizations to discredit what is in fact a scientific consensus. He observed that the tactics were similar to those used by tobacco companies against claims that smoking causes lung cancer (Walsh, 2011).

Can any use of technology be completely compatible with the ecosystem? Clearly modern technology has compatibility problems. But what about earlier technology? We think of agricultural technology as a paradigm of nature itself. However, the classical technology of cities has always collapsed, normally through adopting practices which were incompatible with sustaining their populations. So it seems that even this technology has compatibility problems.

Modern technology does not contain within itself a way out of our conflicts with nature. Indeed, proponents of technology tend to argue that for any problem, there is a further technological fix. But such fixes take us farther and farther away from any recognizably sustainable world. Not only do we end up existing for the sake of our technology, but the technological apparatus becomes increasingly susceptible to catastrophic failure.

Modern technology, though powerful and useful, also contains great dangers in unforeseen and unforeseeable side effects. Thus to minimize serious harm to the ecosystem, new uses of modern technology should be as carefully investigated as possible. Any potential for harm should be evaluated, if possible, in advance of deployment of the technology. However, our actual practice is the exact opposite. The initiation and deployment of new technology is almost entirely the responsibility of corporations. And corporations are motivated to downplay side effects on the ecosystem or even work toward denial of the very existence of side effects.

A corporation is a legal entity capable of acting in some respects as an individual, mainly in terms of property rights, legal liability, and political rights. Theoretically corporations are created to serve the public benefit, ${ }^{3}$ and their trans-individual status allows then to function more efficiently, without constant shifting of property rights and responsibilities ("Corporation," n.d.) A corporation, as a legal construct created for reasons of efficiency, clearly should not inherit all the rights of the individuals making it up. ${ }^{4}$ When corporations have the rights of people, they should also be liable to the same punishments as people--if they kill, they should be executed or prohibited from doing business for some period. This is currently not the case.

When in the 1800 s, corporations were relieved of any public interest concerns, what was left was the goal of maximizing profits. Corporations per se have no social or ethical goals. Some ob-

\footnotetext{
${ }^{2}$ Incredibly, blogger Doug L. Hoffman uses an almost identical diagram to deny man-made influence in the carbon cycle. The name of his website, theresilientearth.com is a tipoff: Humans can do whatever they please to the planet and the "resilient earth" will take care of it. A convenient but dangerous fantasy.

${ }^{3}$ The first versions of corporations in the 1800 s included explicit requirements for corporations to serve the public interest. These requirements were dropped by the end of the 1800s (Adams, 2013).

${ }^{4}$ The 2010 Supreme Court decision Federal Elections Commission vs. Citizens United decided that corporations deserved the individual right of free speech, continuing a string of thoughtless Supreme Court decisions. As my student Tim Duncan observed, although corporations can buy and sell each other, and people can buy and sell corporations, corporations cannot buy and sell people, nor can people buy and sell each other. Therefore, corporations are not people and there is no reason to treat them as such.
} 
servers have pointed out that corporate behavior is similar to sociopathic behavior. Many corporations claim that they practice 'corporate social responsibility.' But on inspection, corporate social responsibility always takes a back seat to the aim of maximizing profits. And the people running corporations are currently constrained only by the directive to maximize profits. Social activist Michael Lerner states clearly that "even the corporate executives with the highest level of spiritual sensitivity ... have no choice but to accept corporate profits as the absolute bottom line" (Lerner, 2000, p. 311). It is the overriding goal of maximizing profits which dovetails so neatly with the essence of modern technology.

Exxon Mobil had the head of the Intergovernmental Panel on Climate Change (IPCC) replaced, not for scientific reasons but because they thought if fossil fuels were held responsible for climate change it would threaten their profits. It has recently come to light that Exxon-Mobil, the largest fossil fuel company, as well as the largest corporation on the planet, has long been aware that human-caused increases in carbon dioxide are causing climate change. In spite of this, they have spent over \$100 million since 1997 to fund climate change denial. So it is not a matter of getting these corporations to "see the light" of scientific truth. It is rather a matter of getting these corporations to abandon their defining aim of making profits at all costs. This accords very much with the insights of Naomi Klein $(2011,2014)$ on dealing with climate change.

Previous cases of corporate denial of environmental problems should have been a warning: Dupont declared that the theory that its chlorofluorocarbons were causing the disappearance of the ozone layer was "rubbish." Tobacco companies for years disputed a causal link between smoking and lung cancer. Science is one of our most powerful and reliable tools for relating to reality. There is no question which should be followed if there is a direct dispute between science and corporations.

Thus the real danger is that corporations acknowledge reality yet distort reality to serve their own ends. They are a human legal construct which has acquired the powers of action of actual human beings, in fact greater powers. Not only are they not ethical individuals with all that that implies, they are not even sentient beings--with all that that implies. They can neither suffer nor be glad; they can neither be angry nor serene; they can neither be hungry or satisfied; they can neither wonder at a marvel of nature nor be appalled at nature's destructive force. They can be productive and efficient but dangerous in their ability to impact beings whose interests are intimately tied up with all the feelings just enumerated. Can we hope that the disconnect of corporations and the environment will ultimately be recognized by enough human beings so that we can deal with it appropriately?

\section{Extinction}

Eventually the human race will become extinct, like any other species. We can distinguish several kinds of extinction:

- Gradual extinction

- Better adapted species replaces old one

- Ecological niche for species no longer available

○ By human actions

- Sudden extinction.

- By natural processes external to human beings

- By human actions 


\section{Gradual Extinction}

Species of living things on this planet have an average life span of two million years. So gradual extinction would be analogous to individual death from old age. The species would simply have run its course in nature, its numbers would diminish, and finally there would be no more human beings, members of the species Homo sapiens.

Within this scenario, there are two other possibilities: either there are similar but better adapted species which supersede Homo sapiens, or the ecological niche Homo sapiens occupies is itself no longer available. ${ }^{5}$

The existence of similar but better adapted species--namely us-- is exactly what caused the extinction of our predecessor species Homo erectus, Homo sapiens neanderthalis, and perhaps others. It is difficult, however, to see how a separate population of genetically different humans could maintain themselves in the current state of human civilization. With physical communication worldwide, any mutation would be fairly quickly incorporated into our world wide gene pool. Evolutionary biology tells us that the appearance of a new species superseding an older one requires the physical separation of part of the older species population. This process, called macroevolution, can produce a new species in the separated population by natural selection or even simple genetic drift. ${ }^{6}$

The second gradual extinction possibility, the disappearance of our ecological niche, seems most likely as the result of accumulated environmental changes caused by us. For example, a recent dramatic decrease in the fertility of human sperm may have been caused by increased air and water pollution in the environment. ${ }^{7}$ If this trend gets dramatically worse, one could see the human population diminishing to zero. Of course, one would expect human beings to take steps to reverse this trend well before extinction took place. But there could well be environmental effects on fertility or other critical factors for species survival whose causes elude us long enough to cause extinction.

Extinction caused by human beings can be either gradual or sudden. Gradual extinction of this kind would be humans setting in motion unstoppable processes which take a long time to run their course. Current changes to greenhouse gases in the atmosphere may be processes of this kind. An example of sudden extinction caused by humans would be nuclear war.

\section{Sudden Extinction}

The likelihood of sudden extinction may be greater. There are also two types of sudden extinction: those caused by natural processes completely external to human beings and those caused by human action. External causes of extinction are collisions with asteroids or comets, or massive volcanic eruptions. Both have caused mass extinctions in the past. An asteroid collision 60 million years ago in the Yucatan most likely caused the extinction of the dinosaurs (Bryner, 2015).

\footnotetext{
${ }^{5}$ Another theoretical possibility is that some species we kill for our survival develops an unbeatable defense (Colby, 1996). This is highly unlikely to happen to human beings with their physical superiority.

${ }^{6}$ I am grateful to Andrew Ross for clarification about the mechanism of macroevolution. See also Colby, 1996.

${ }^{7}$ E. Carlsen and his associates published in 1992 a study "Evidence for Decreasing Quality of Semen During Past 50 Years" (Carlsen, Giwercman, Keiding, \& Skakkebæk, 1992). In a 1996 book, Our Stolen Future, Colborn, Dumanoski, and Myers, argue that industrially-derived "hormone disrupters"--particularly chemicals that behave like estrogen and interfere with fetal development--threaten our ability to reproduce. Of course corporations dependent on the unregulated production of these chemicals stepped in to discredit these conclusions.
} 
And 70,000 to 80,000 years ago the supervolcanic eruption at what is now Lake Toba in Sumatra most likely came close to extinguishing Homo sapiens. Some estimate that as few as between 1,000 and 10,000 humans survived (Ambrose, 1998). Another example would be the earth's being an unlucky target of a gamma ray burst (Minard, 2009). Such events are not predictable. A probable human cause of sudden extinction is nuclear war, to be discussed further shortly.

Nevertheless, once our species goes extinct, is it any consolation that the extinction happened as a result of normal evolution or the action of natural processes? This is just not parallel to death because of old age, unless there is a successor species. And there is good reason to believe there will not be a successor species to globalized humanity.

Eventually conditions on the earth will not permit life, as when the sun expands out beyond earth's orbit. Of course we may be able to postpone this fate by moving to another habitable world. But this only postpones the inevitable. The entire universe will one day become uninhabitable as the expansion of the universe eventually dilutes all energy to the point nothing can be done (Baez, 2016). So there is also a definite time frame within which life exists, whether on earth or elsewhere. ${ }^{8}$

\section{Human Extinction}

Modern technology has no regard for the ecosystem as such, and the ecosystem is necessary for human survival. So it is necessary to raise the question whether some implementations of technology might result in human extinction. In this paper the following dangerous implementations of modern technology will be briefly discussed. Extinction caused by any of these could be gradual or sudden human extinction.

1. ozone layer depletion through chlorofluorocarbons

2. fossil fuel usage producing global warming and climate change

3. nuclear war and nuclear contamination.

4. plastics

5. genetic engineering

6. habitat destruction

\section{(1) Ozone layer depletion through chlorofluorocarbons}

Chlorofluorocarbons and their effect on the ozone layer make it clear that extremely damaging consequences of our technological changes cannot always be predicted. Chlorofluorocarbon (CFC), a "safe" synthetic compound, was developed in the 1940s for use in air conditioners and aerosol cans. Its inventor actually drank a glassful of CFCs at a press conference to demonstrate their safety. Indeed, CFCs are chemically inert except in the upper atmosphere, where they destroy the ozone layer which protects us from ultraviolet radiation. The ozone layer protects all life against excessive ultraviolet radiation, and when it is damaged or destroyed, the surface of the planet on which we and all animals and plants live, is subjected to dangerous levels of ultraviolet. Since all life has evolved under the protection of the ozone layer; its removal would have unpredictable consequences for all life forms in the ecosystem (Asimov \& Pohl, 1991, pp. 91-110). Extinction, both of humans and all life, is a possibility, but one that would be almost impossible to evaluate until the consequences of no ozone start rolling in. We know cancer, in particular skin cancer, would increase by huge amounts. Also the amount of time it would be possible to remain outdoors without incurring severe sunburn would decrease likely to less than a minute. Animals and plants usually do not have the option of moving indoors, so very deleterious effects on them would occur.

\footnotetext{
${ }^{8}$ Further discussion of these issues can be found in Schultz (2014, Ch. 14).
} 
One reassuring development is that all nations have recognized the threat and accepted the Montreal Protocol. This protocol bans the use of chlorofluorocarbons, and the ozone layer is expected to recover fully by about 2050. However, in 2012 an entirely different threat to the ozone layer emerged: More severe thunderstorms caused by global warming were found to be depositing ozone-destroying material in the ozone layer (Fountain. 2012). Thus we also have no way of knowing how long our solutions will continue to work.

Extinction by introduced man made chemicals could be slow, could be fast. If the ozone layer slowly vanishes, there may be time to deal with it or even for organisms to adapt to the increased UV radiation. It has been noted that if the original chemist had based his compounds on boron rather than chlorine, the ozone layer would have been gone before we even noticed. If someone at this point were to propose a technological solution, I would say that they have not been paying attention.

\section{(2) Fossil fuel usage producing global warming and climate change}

There is consensus that there is a relatively short window to reduce carbon emissions before drastic effects occur. Recent credible projections of the result of lack of rapid drastic action is an average temperature increase of about $10^{\circ} \mathrm{F}$ by 2050 . This change alone will be incredibly disruptive to all life, but will also cause great weather and climate change. For comparison purposes, a 10 degree (Fahrenheit) decrease was enough to cause an ice layer 4000 feet thick over Wisconsin (Co2gether, 2012). Recently relevant information has surfaced about a massive previous extinction. This is the Permian extinction, which happened 252 million years ago, during which $95 \%$ of all species on earth, both terrestrial and aquatic, vanished. The ocean temperature after almost all life had disappeared was 15 degrees (Fahrenheit) above current ocean temperatures.

Recent information about the Permian extinction indicates it was caused by a rapid increase in land and ocean temperatures, caused by the sudden appearance of stupendous amounts of carbon in the form of greenhouse gases (Kolbert, 2014, pp. 102-144). The origin of the carbon in these enormous quantities is not yet known, but one possibility is the sudden release of methane gases stored in permafrost. This is also a possibility in our current situation. If so, extinction would be a natural side effect of human processes. There is also a real but smaller possibility of what is called "runaway greenhouse," in which the earth's temperature becomes like Venus' surface temperature of $800^{\circ}$

The threat of extinction here is not entirely sudden. The threat is, if anything, worse. Changes in the atmosphere--mainly increases in the concentration of greenhouse gases in the atmosphere-can start processes that can't be reversed but which take long periods of time to manifest. "Runaway greenhouse" may be the worst. Once again, suggestions of technological solutions to this situation should be treated with some skepticism. These proposals are often made by technophiles ignoring all the evidence that technology is very much subject to unanticipated side effects and unanticipated failures. What has happened concerning the depletion of the ozone layer should be a clear warning against the facile uses of technology through geoengineering to alter the makeup of the entire planet and its atmosphere.

The complicating factor in assessing extinction likelihood from climate change is corporations, especially American fossil fuel corporations such as Exxon-Mobil and Shell. Through their contributions, they have been able to delay legislation ameliorating global warming and climate change. As mentioned before, recently released papers from Exxon-Mobil show that the corporation did accept the scientific findings about global warming and climate change. But they concluded that maintaining their profits was more important than acting to ameliorate climate change. 
Since it is not a matter of getting corporations to appreciate scientific facts, the chances of extinction from climate change are good. To ameliorate climate change, it is important to leave a high percentage of fossil fuel reserves in the ground. But this is exactly what a profit-seeking fossil fuel corporation cannot do. One can still hope that because fossil fuel corporations are made up of individuals, increasingly bad consequences of global warming and climate change will change their minds about profits. But because of the lag in effects, this mind change will probably be too late. So I conclude we will probably see something like the effects of the Permian extinction perhaps some time around 2050. (The Permian extinction was 95\% extinction of all species.) This assumes the release of methane from the arctic will take place around then.

This conclusion is reinforced by India's recent decision to fuel massive economic development with coal, the worst polluter of the fossil fuels. ${ }^{9}$ So Indian calculations apparently show that economic development is more important than human survival.

\section{(3) Nuclear war and nuclear contamination}

Proliferation of nuclear weapons among states that are politically or emotionally unstable raises the threat that the irrationality of their use may not prevent that irrational use. There is also the possibility that some group that is not a state may use them as a terrorist tactic. It has also been argued that as long as nuclear weapons exist, there is a statistical probability they will eventually be set off.

Although no one denies that nuclear war is a bad thing ${ }^{10}$, this is not true of nuclear energy. In spite of the threat of contamination from malfunctioning nuclear reactors--as from the tsunamidamaged reactors at Fukushima-- economic interests known as the "nuclear power industry" disseminate propaganda dismissing any serious danger. The problem of long-term storage of radioactive waste from nuclear reactors to prevent contamination of the environment also goes unsolved. The problem is that some waste must be sequestered from the rest of the environment for periods on the order of 20,000 years. This is more than double the time period that civilization has existed, let alone in a stable enough form to guarantee actions and policies lasting that long.

Nuclear war could clearly cause sudden extinction. Jonathan Schell (1982) has definitively outlined the consequences of nuclear war. Huge clouds of particulates surrounding the planet would block the sun for significant periods. Extinction rates would be similar to those experienced by the dinosaurs under similar conditions.

When nuclear reactors seriously malfunction in a meltdown, environmental impacts are severe. Large portions of inhabitable land become uninhabitable. If reactors proliferate with no control, a series of meltdowns could render more land uninhabitable than is needed for human habitation. Not by itself an extinction, but definitely on the road to that end.

\section{(4) Plastics}

Other man-made substances can also cause harm. Perhaps from the point of view of the ecosystem, the worst of these products are non-toxic plastics, derived from fossil fuels such as petrole-

\footnotetext{
${ }^{9}$ So-called "clean coal" is an economic absurdity. It is supposed to work like this: At some expense and great ecological degradation, you dig up the coal. Then you burn it with expensive techniques to segregate the carbon. Then at some expense you re-bury the carbon. It is obviously less expensive and ecologically destructive to leave the carbon in the ground and generate the energy in some other way. Unless you own coal mining rights.

${ }^{10}$ Apparently top generals during Kennedy's presidency seriously proposed starting a nuclear war with the Soviet Union. Kennedy vetoed the proposal, which may have had something to do with his assassination.
} 
um. Because most such products are non-biodegradable, they do not participate in natural recycling. Plastics disintegrate into smaller pieces, right down to the level of molecules. These smaller pieces are non-biodegradable, they remain in the environment. Instead, natural components recycled into the ecosystem become mostly water and oxygen. The area known as the Great Pacific Garbage Patch in the northern Pacific Ocean has the highest levels of decomposed plastic on the planet. Before it disintegrates, plastic kills as many as 100,000 marine animals who mistake it for food. When decomposed, plastic still enters the food chain and accumulates in animals higher in the food chain (Amaral, 2003). A similar patch has appeared in the North Atlantic.

On land, plastics--single-use bags and packaging--are a major component of landfills (Berkeley Plastics Task Force, 2009). The bags will eventually break down--in 1000 years. Even then, the molecular components will persist indefinitely. "Every year, more than 500 billion plastic bags are distributed, and less than 3\% of those bags are recycled." Even when recycled, they become lower grade plastic not reusable as bags. Hence recycling does nothing to reduce the production of plastic bags (Ecology Center, 2011).

Petroleum-based fertilizers are in some ways similar to plastics. They are not especially toxic, and are beneficial when used for their intended purpose of enabling plant growth. Indeed, these fertilizers are credited with dramatically increasing agricultural yields. However, they invariably are washed into nearby streams and rivers. There they make those rivers and streams unusable for drinking and swimming. They are a major cause of lake eutrophication Eutrophication occurs when a lake overdoses on nutrients such as nitrogen and phosphorus. Algae bloom in large numbers, making the lake cloudy and removing oxygen for fish. At the end process the lake becomes stagnant, smelly, and loaded with dead fish and they eventually create dead zones in the ocean at the mouths of rivers. Because of the increased yields, farmers and especially agribusinesses treat the fertilizer pollution as a regrettable side effect.

When synthetic laundry detergents replaced soap in the 1940s and 1950s, an increase in water problems began to emerge (Knud-Hansen, 1993). Phosphates added to laundry detergent dramatically improved the cleaning efficacy of detergents. But this ingredient, phosphate, causes severe eutrophication. It has been limited or banned from laundry detergents in many states in the US, Canada, the EU, and Japan. Substitute ingredients have been found which have similar cleaning ability but which do not cause eutrophication. However, phosphates are still present in dishwasher detergents because an effective substitute has not been found (MacIntosh, 2007).

Extinction consequences are again slow and indirect. The impact is on the food supply, especially seafood. As concentrations of plastics in fish increase, they will either die or become less able to reproduce. We can expect knock-on effects in creatures like us that consume seafood. The destruction of productive land by excessive fertilizer use is habitat loss and will be discussed under that topic.

\section{(5) Genetic engineering}

As we have seen, it is characteristic of modern technology that it regards everything as potential resources on call for use in its own processes. From this point of view, we can clearly see the danger in bioengineering. Bioengineering takes DNA, the genetic material governing the continuance of life, and makes changes to it in accordance with short-term human needs. Natural selection, which produced that DNA in the first place, is completely left out. Here the problem is not the technical faultiness or soundness of bioengineering applications but rather manipulation of DNA extraneous to natural selection. This manipulation is functionally identical to the production of random mutations in DNA. In this case, successful mutations are rare. Thus there is a decent chance that DNA manipulation of plants in our food supply could result in the collapse of 
our food supply (Chattsko, 2014). This may not mean total extinction for humanity but collapse of the food supply could easily produce the collapse of civilization, as it has in the past.

\section{(6) Habitat destruction}

Habitat destruction has two important negative effects: extinction of other species and contribution of more carbon dioxide to the atmosphere. Perhaps the most visible is impoverishing the biosphere through the extinction of many plants and animals. Extensive discussion of the issues involved here can be found in Kolbert (2014) and Wilson (2002). The disappearance of many species might seem a matter of aesthetics or human enjoyment of animal and plant diversity such as lions or giant sequoias. It may seem as though humans could continue exist quite well without all these extra species, although not as happily. Biologist Edward O. Wilson tries to justify the preservation of other species as follows: ". . .life forms around us are too old, too complex, and potentially too useful to be carelessly discarded" (2002, p. 131). But then we could still carefully discard any number of life forms that are potentially not profitable for us.

Wilson almost gives a better justification: all life is interdependent in complex ways. Ecosystems cannot be recreated artificially by humans. This is important for the preservation of as many species as possible. We don't know what's important in the ecosystem for our survival, and we don't know what we can remove without potentially disastrous consequences for us. Not only can't we tell what parts of the biosphere will be useful to us, we can't even tell which parts will turn out to be essential for our survival. Thus we could easily produce our own extinction by inadvertently eliminating parts of the ecosystem essential for us.

The other negative effect of habitat destruction is less speculative. Some ways of altering the land can significantly increase the amount of carbon dioxide in the atmosphere, with the resultant negative effects on global warming and climate change. Deforestation replaces trees which absorb carbon, with plants and animals which do not (Kolbert, 2014). Thus global warming is increased. Agriculture itself, especially dairy farming with cattle, produces surprisingly large amounts of carbon (Andersen, 2014).

\section{Information Technology}

Somewhat paradoxically, information technology (IT) is not entirely modern technology. Although computer hardware is part of modern technology, the application of that hardware to the world is not part of modern technology. IT applications do not look to reorder everything in the furtherance of their own aims. IT applications do not reduce everything to information; rather they provide a separate realm where certain processes representing real objects can be carried out incredibly quickly and communicated much more easily. The tendency to confuse this parallel world with the real world was common during the heyday of the dot-com bubble. People were seriously suggesting that mom-and-pop local groceries would need to convert to web businesses in order to survive, that all commerce would be web commerce. But IT applications are a parallel world and there is no reason to expect them to replace the real world. The overreaction to the millennium bug of 2000 may have depended on a similar confusion of the real world with its digital representation

Information technology is also essential for telling us where we stand with respect to the ecosystem, especially about threats to humans and to the ecosystem. Killer asteroids could wipe out both us and the ecosystem, completely resetting the clock of evolution, as happened when the dinosaurs died. The sophisticated instruments necessary for measuring our impacts on the ecosystem are products of modern technology.

If anything is a saving power in our current situation, it is information technology. Its aim is to inform rather than to increase its dominion over the rest of the world. Without the past, present, 
and future use of information technology, we could not begin to know about or solve our current environmental conflicts. Yet for all its value, information technology is like other technology in being liable to unexpected and unpredictable failures. So information technology must be handled with at least as much care as any other. There is no guarantee that there will be no further glitches.

There is no way of sidestepping the problems caused by these features. Unintended and unpredictable consequences are just that. I recall a Dilbert comic strip where the clueless boss demands to be notified in advance of unplanned outages. The case of the ozone layer is sufficient by itself to show that we need to minimize modern technology. It is worth repeating that chlorofluorocarbons, apparently useful and unique substances produced by modern technology, were destroying the ozone layer. It was touch and go to get the international agreement ${ }^{11}$ which phased them out. Also, if the chemist who created chlorofluorocarbons had happened to have based his product on bromine rather than chlorine, the ozone layer would have been gone before we knew what hit us ${ }^{12}$.

Modern technology is just not safe. Climate change is another instance. Carbon dioxide is not a pollutant at ground level. In the upper atmosphere, it functions as a greenhouse gas, trapping more of the sun's heat. One of the reasons why people can't accept the straightforward science of climate change is that they see that they can't accept climate change and preserve modern technology. To preserve modern technology, they have to reject the idea that human technology is unintentionally causing conditions which can do serious harm to humans and living things.

We are now dependent on modern technology for many aspects of our survival, especially in the developed world. Therefore, modern technology must be reduced rather than eliminated. Some parts of modern technology probably should be terminated immediately, whereas other parts may have to remain if they can be employed without serious risk. And most IT applications, for example, those needed to monitor the state of the climate, must be retained even if there is some risk. As mentioned previously, IT allows us to have the knowledge we need to continue to be a part of the world we live in.

\section{Conclusion}

Two features of modern technology tend to make it contribute to human extinction: first, modern technology's tendency to produce unintended and unpredictable side effects; second, modern technology's treating everything (including the ecosystem) as resources to be exploited. The two features are connected. Because modern technology has no respect for the integrity of the ecosystem in its processes, it is no wonder that unintended and unpredictable side effects for the ecosystem occur with some frequency.

However, some forms of modern technology need to continue to be deployed regardless of the risks. IT is especially notable because it is our only means of determining risks to the ecosystem. IT also does not displace or damage the rest of the world as do so many applications of modern technology.

Any species is liable to extinction if it cannot deal with its environment intelligently. This includes environmental change, as the dinosaurs unhappily discovered. It also includes environment created by the species itself, as human beings have done extensively. The environment, after all,

\footnotetext{
${ }^{11}$ The Montreal Protocol. See the discussion in Schultz 2014, Chapter 10, Environmentalism and Sustainability.

${ }^{12}$ Mark Lynas supplies most of this information in his The God Species (2011), boundary 9. Being a technophile, he does not draw my relatively obvious conclusion.
} 
is what supports the life of creatures of that species. I would hope that this paper and related work contributes to a greater awareness of the potentially serious malfunctions of modern technology.

\section{Acknowledgements}

I would like to thank the Institute for Transdisciplinary Studies at Woodbury University for initial support. Thanks for further support are also for the generosity of Andre van Niekerk, as well as the support of John Tenney and Grazina Keeley.

\section{References}

Adams, G. M. (2013). Our hidden history of corporations in the United States. Retrieved 4/11/2013 from http://reclaimdemocracy.org/corporate-accountability-history-corporations-us/

Amaral, K. (2003). Plastics in our oceans. Woods Hole Institute. Retrieved 10/31/11 from www.whoi.edu/science/B/people/kamaral/plasticsarticle.html

Ambrose, S. H. (1998). Late Pleistocene human population bottlenecks, volcanic winter, and differentiation of modern humans. Journal of Human Evolution, 34, 623-651.

Andersen, K. (2015). Cowspiracy [film]. Santa Rosa, CA: A.U.M. Films \& Media.

Asimov, I., \& Pohl, F. (1991). Our angry earth. New York: Tom Dougherty Associates.

Baez, J. (2016). The end of the universe. Retrieved 3/06/16 from http://math.ucr.edu/home/baez/end.html

Berkeley Plastics Task Force. (2009). Campaign against the plastic plague: Background info. Earth Resource Foundation. Retrieved 10/31/11 from www.earthresource.org/campaigns/capp/cappbackground-info.html

Bryner, J. (2015). Dinos died here: Getting to the core of asteroid impact mystery. Live Science, April 08. Retrieved from http://www.livescience.com/50414-chicxulub-crater-drilling.html

Carlsen, E., Giwercman, A., Keiding, N., \& Skakkebæk, N. E. (1992). Evidence for decreasing quality of semen during past 50 years. British Medical Journal, 305(6854), 609-613. Retrieved 9/17/11 from www.jstor.org/pss/29716905 [Unfortunately access to this important article is limited to those with institutional affiliation or substantial financial wealth.]

Chattsko, M. (2014). Is Nassim Taleb right about Monsanto Company and GMOs? The Motley Fool $3 / 9 / 2014$.

Colburn, T., Dumanoski, D., \& Myers, J. (1996). Our stolen future. New York: Dutton.

Colby, C. (1996). Introduction to evolutionary biology. Version 2. Retrieved 9/15/11 from www.talkorigins.org/faqs/faq-intro-to-biology.html

Co2gether. (2012). Understand climate change. Co2gether. Retrieved 1/31/12 from www.co2gether.org/my co2/understand/

Corporation. (n.d.). In The Free Dictionary. Retrieved 11/1/04 http://legaldictionary.thefreedictionary.com/Corporation

Doran, P. T., \& Zimmerman, M. K. (2009). Examining the scientific consensus on climate change. Eos Transactions American Geophysical Union, 90(3), 22-23.

Ecology Center. (2011). Plastics task force: Seven misconceptions about plastic and plastic recycling. Retrieved 10/31/11 from www.ecologycenter.org/ptf/misconceptions.html

Fountain, H. (2012, July 26). Storms threaten ozone layer over U.S., study says. New York Times, July 26, 2012. Retrieved 8/10/12 from http://www.nytimes.com/2012/07/27/science/earth/strong-stormsthreaten-ozone-layer-over-us-study-says.html? $\mathrm{r}=0$

Hansen, J. (2009). Storms of my grandchildren. New York: Bloomsbury USA. 
Heidegger, M. (1955). The question concerning technology. In M. Heidegger, The question concerning technology and other essays (pp. 3-36). New York: Harper \& Row

Klein, N. (2011). Capitalism vs. the climate. The Nation, November 9.

Klein, N. (2014). This changes everything. New York: Simon and Schuster.

Knud-Hansen, C. (1994). Historical perspective of the phosphate detergent conflict. Conflict Resolution Consortium, University of Colorado. Retrieved 10/31/11 from www.colorado.edu/conflict/full text search/AllCRCDocs/94-54.htm

Kolbert, E. (2014). The sixth extinction. New York: Henry Holt.

Lerner, M. (2000). Spirit matters. Charlottesville, VA: Hampton Roads Publishing.

Lynas, M. (2011). The God Species. Washington, DC: National Geographic Society.

MacIntosh, H. S. (2007). What's the dirt on phosphate-free soaps? March 27, 2007. Retrieved 11/1/11 from www.treehugger.com/culture/ask-treehugger-whats-the-dirt-on-phosphate-free-soaps.html

McKibben, B. (2015). What Exxon knew about climate change. The New Yorker, 9/18/2015.

Minard, A. (2009). Gamma-ray burst caused mass extinction? National Geographic News, April 3, 2009. Retrieved 5/9/12 from http://news.nationalgeographic.com/news/2009/04/090403-gamma-rayextinction.html

Schell, J. (1982). The fate of the earth. New York: Knopf.

Schultz, R. (2014). Technology versus ecology: Human superiority and the ongoing conflict with nature. Hershey, PA: IGI Global Press.

Walsh, B. (2011). Who's bankrolling the climate-change deniers? Time, Oct. 04, 2011. Retrieved 11/4/11 from http://www.time.com/time/health/article/0,8599,2096055,00.html

Wilson, E. O. (2002). The future of life. New York: Vintage Books

Zimmer, C. (2010, Dec.22). Siberian fossils were Neanderthal's eastern cousins, DNA reveals. New York Times. Retrieved 9/17/11 from www.nytimes.com/2010/12/23/science/23ancestor.html

\section{Biography}

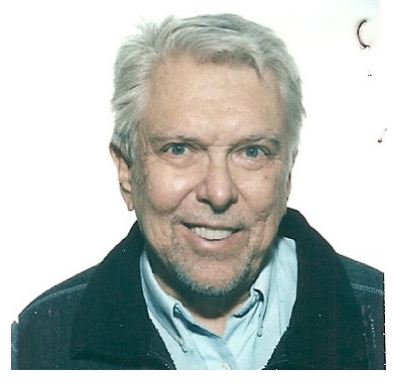

Robert A. Schultz received his Ph.D. in philosophy from Harvard University in 1971 with a dissertation in ethics under John Rawls. In 1980 he became Data Processing Manager at A-Mark Precious Metals, in Beverly Hills, CA. He was Professor and Chair of Computer Information Systems at Woodbury University from 1989 until he retired in 2007. For some years, he taught an online course in IT and Ethics for the AIM Masters Program at the University of Oregon. He has published in the areas of database design, IT and ethics, and the philosophy of technology. He has also published three books with IGI-Global Press on topics in IT, ethics, and ecology. 